\author{
Arkadiusz Morawiec \\ (D) https://orcid.org/0000-0001-6424-1194 \\ The University of Łódź
}

\title{
Polish Literature and the Extermination of the Soviet Prisoners of War*
}

\begin{abstract}
The article addresses the motif (and theme) of the Soviet prisoners of war in Polish literature. It presents historical facts which have inspired literary representations of events concerning the complex fates of the Soviet POWs both during the German-Soviet war (1941-1945) and after it came to its end. It also offers a discussion on the political and ideological determinants of the literary portrayal of the prisoner of war. Texts subjected to analyses include both works of fiction and memoirs, such as, among others, Igor Newerly's Chłopiec $z$ Salskich Stepów (The boy from the Steppes of the Sal), Seweryna Szmaglewska's "Zagrycha" (The snack), or Wiesław Kielar's Anus Mundi. 1,500 Days in Auschwitz/Birkenau. Particular attention is given to Wisława Szymborska’s poem "The Hunger Camp at Jasło" (“Obóz głodowy pod Jasłem”).
\end{abstract}

Keywords: Polish literature, theme, motif, genocide, Nazi crimes, war crimes, Soviet prisoners of war

Addressing the fates of the Soviet prisoners of war, Polish literature most frequently mentions those who were deported to Auschwitz and who, in the grand majority of cases, were annihilated there. In fact, however, it is not this most infamous of all death camps in the world that became the chief site of their torment and extermination. According to various estimates, between five and eight hundred thousand Red Army prisoners of war lost their lives not only in concentration and extermination camps, but also in the dozens of POW camps

* The present text is a part of a more extensive project on the subject of the extermination of Soviet prisoners of war as represented in Russian and Polish literatures. Basic historical facts concerning the extermination of Soviet POWs and a discussion on how it is reflected in Russian literature have been presented in my article "Literatura rosyjska wobec zagłady sowieckich jeńców wojennych" in the present issue (Narracje o Zagładzie 2020, no. 6), pp. 80-114. 
located - among others - within the territories of the Nazi-occupied Poland. ${ }^{1}$ In the first months of the Soviet-German war, the largest group of victims were not, as one could think, ethnic Poles or Jews, but the Soviet prisoners of war, detained in Stalags and Oflags, and dying en masse. ${ }^{2}$ For example, in Stalag 307 in Dęblin, which consisted of four sub-camps, about 80,000 Red Army POWs lost their lives. ${ }^{3}$ The number of victims of Stalag 319 in Chełm (including its sub-camps and subsidiaries) is estimated at around 98,000 - of which number a grand majority were the Soviets. ${ }^{4}$ To clearly emphasize the scale of the genocide perpetrated in sites less widely known than the death camps, it is worth taking into account that the number of lives lost in the Majdanek concentration camp - which, next to Auschwitz, is another world-recognized symbol of the Nazi crimes - amounts, as research demonstrates, to ca. 78,000. ${ }^{5}$

With this information in mind, let us now move on to the discussion on literature, which, in the context of this article, I understand in the broad sense of the word, that is, as a body of texts comprising fiction, memoirs, as well as other non-fictional narratives derived from individual reminiscences. In December 1942, an anonymous brochure titled The Camp of Death was circulated in Warsaw. The booklet concerned Auschwitz, or more precisely the main camp. The author, as it later became known, was Natalia Zarembina, who based her text on the accounts of Edward Bugajski, Eryk Lipiński, and Henryk Świątkowski, prisoners released from the camp. ${ }^{6}$ Next to its documentary merits, the brochure also shows traits of a literary text. It consists of an introduction and ten chapters; the eighth chapter informs the reader that "500 Bolsheviks" and "sick Poles brought in from hospital" were gassed to death in one of the "barracks" (in fact: "blocks"), and that several days later their bodies were transported to the crematorium under cover of the night. ${ }^{7}$

${ }^{1}$ See G. Мотүка: “Tragedia jeńców sowieckich w czasie II wojny światowej w polskiej historiografii.” In: J. WојткошіAK (ed.): Jeńcy sowieccy na ziemiach polskich w czasie II wojny światowej. Warszawa 2015, pp. 21, 23.

${ }^{2}$ See T. Snyder: Bloodlands. Europe between Hitler and Stalin. New York 2010, pp. 180-181.

${ }^{3}$ See G. Мотүка: “Tragedia jeńców sowieckich...," p. 23.

${ }^{4}$ Next to the Soviet prisoners of war, Stalag 319 was also the prison to the captured French, British, Belgian, and Italian soldiers, and - in the final period of the camp's operations - it was to Stalag 319 that the guerillas of the 27th Volhynian Infantry Division of the (Polish) Home Army, captured during the "Storm" operation, were deported. See A. Ryвaк: "Losy jeńców sowieckich w Stalagu 319 w Chełmie." In: Jeńcy sowieccy na ziemiach polskich..., p. 36.

${ }^{5}$ See T. Kranz: “Ewidencja zgonów i śmiertelność więźniów KL Lublin.” Zeszyty Majdanka 2005, vol. 23, pp. 7-53.

${ }^{6}$ [N. Zarembina]: Obóz śmierci. [Warszawa] 1942. For more information on the brochure, see: A. Monawiec: Literatura $w$ lagrze, lager $w$ literaturze. Fakt - temat - metafora. Łódź 2009, pp. 91-93.

7 [N. Zarembina]: The Camp of Death. With a foreword by J.L. Adamson [Trans. B. GaDOMSKA]. London 1944, pp. 22-23. 
The description of the crime culminates in the following paragraph, which reveals the author's writerly ambitions:

The secret of the vaults, from which nobody ever returned, filters through with the dawn of a new day. The secret of 800 people killed is revealed.

To the short "tune," beginning with the steps on the gravel, the words are found. They killed them with gas. ${ }^{8}$

It is not impossible that Zarembina's text could be the first publication informing the world of the "test," with which the serial use of the Zyklon B as means of putting people to death began - and the majority of its victims were Jews.

A more direct description of this and other crimes perpetrated on the Soviet prisoners of war in KL Auschwitz may be found in Wiesław Kielar's Anus Mundi. ${ }^{9}$ The author presents his account of these events in a few brief chapters of his memoir. He reminisces thus:

As we returned from the crematorium we were stopped by the guards, who told us to collect another batch of corpses from the gravel pit. This time it was a group of Soviet prisoners of war who had been taken to the camp straight from the battle area in the east and quickly killed. ${ }^{10}$

He also describes the extermination of the Soviet POWs and of the group of the ill Polish prisoners, carried out on September 3rd, 1941: "everybody had been gassed," he writes, "about a thousand corpses."11 Along with other prisoners, he was made to carry the dead bodies out of the bunkers of Block 11 to the transport carts. Further in the text, he describes the next group of the Red Army POWs arriving at the camp in the beginning of October, from the perspective of a member of the "disinfecting team," 12 to which he was assigned:

They were hungry, emaciated, frozen and incredibly filthy. [...] Towards morning the last group of a hundred naked prisoners left the fenced spot. The stronger ones were carrying their totally exhausted comrades on their shoulders. The ground, covered with snowflakes, was wet, trampled by thousands of feet. Piles of prisoners' clothing were lying about: boots, metal bowls, leftovers of more than ten thousand people who had been driven into the camp. ${ }^{13}$

8 Ibidem, p. 23.

9 W. Kielar: Anus Mundi. 1,500 Days in Auschwitz/Birkenau. Trans. S. Flatauer. New York 1980. The original text was written in Polish; see W. Kielar: Anus mundi. Wspomnienia oświęcimskie. Kraków 1972.

10 Ibidem, p. 60.

11 Ibidem, pp. 61-62.

12 Ibidem, p. 71.

13 Ibidem, pp. 71, 73. The "other" perspective, that is, the perspective of a Soviet prisoner, who arrived in Auschwitz on October 7th, may be found in the memoir of Andrey Pogozhev 
In his account, Kielar does not shy away from sarcasm:

Within the next few weeks [of October and November - A.M.] these "brave" SS men achieved such outstanding "success" with the Soviet prisoners of war that they could no longer cope with the incinerating of corpses in the crematorium and, for that reason, were forced to bury thousands of dead bodies in the long ditches by the forest of Birkenau, where presently the construction of a new camp was started. ${ }^{14}$

Initially, one should add, the construction was carried out with the hands of the few surviving Soviet prisoners of war.

In her Smoke over Birkenau (published in December 1945), Seweryna Szmaglewska includes a brief comment concerning the liquidation of the Birkenau camp towards the end of 1944 :

In the work of wrecking the barracks, the women are helped by the Russian prisoners captured in recent battles. These war prisoners are treated abominably, with the violation of every right to which a war prisoner is entitled. Officers, sometimes of high rank, are thin and starved and forced to labor at backbreaking tasks. Often they are driven harder than other prisoners in the concentration camp. ${ }^{15}$

It is probable that the described Red Army prisoners of war had been transferred to Birkenau from other camps (as was, for instance, the case of a group of 109 people from the POW camp in Lamsdorf, who were moved to Birkenau on August 5th, 1944). ${ }^{16}$

In 1958 Szmaglewska published another story - more precisely, a humoresque offering a glimpse into the tormented life of the Soviet prisoners of war at Auschwitz. The plot of the story, titled "Zagrycha" (The snack), ${ }^{17}$ is set in 1944 in the

titled Escape from Auschwitz (A. Pogozhev: Escape from Auschwitz. Trans. V. Krupnik, J. ArmStrong. Barnsley 2007; original text: А.А. Погожев, П.А. Стенькин: Побег из Освенцима. Остаться в живых. Москва 2005), p. 16 of the original text (et passim). One should add that as of October 7th, 1941, the Soviet prisoners, whose number, indeed, initially amounted to ca. 10,000 , would be brought to Auschwitz in several transports from the Stalags 308 Neuhammer (Świętoszów), 318 Lamsdorf (Łambinowice), and 327 Jaroslaw (Jarosław). See J. Lachendro: Jeńcy sowieccy w KL Auschwitz. Oświęcim 2016, p. 15.

${ }_{14}$ W. Kielar: Anus Mundi..., pp. 73-74.

15 S. Szmaglewska: Smoke over Birkenau. Trans. J. Rynas. Auckland 2015, p. 421.

${ }^{16}$ See D. Czech: "Kalendarz najważniejszych wydarzeń z dziejów KL Auschwitz." In: W. DŁugoborski, F. Piper (eds.): Auschwitz 1940-1945. Węzłowe zagadnienia z dziejów obozu. Oświęcim 1995, vol. 5, p. 134.

17 S. Szmaglewska: "Zagrycha." In: Chleb i nadzieja. Opowiadania. 2nd extended ed. Warszawa 1960, pp. 56-67. Unless marked otherwise, all quotations in the text have been translated into English by Paweł Jędrzejko. 
Zerlegebetrieb Kommando, whose task was to dismantle the allied aircraft shot down in air battles and raids, and to harvest parts from the German aircraft withdrawn from service. The protagonist of the story is a stubborn prisoner; his antagonist is a camp guard, who catches the "Russkiy" in the act of draining alcohol from the wrecked fuselage. Curious as to how much pure alcohol the Russian can really take, the guard asks the question. When the prisoner responds that he can drink a hundred grams of pure alcohol more than the guard could drink of regular vodka, the latter, confident of his victory, challenges the prisoner to a drinking competition. They both drink themselves into oblivion. When the Kommando returns to the camp, the Russian, having sobered up, regains his appetite, and his fellow prisoners give him "a fat snack" to alleviate the after-effects of drinking. Soon they all learn that the SS man ended up jailed in the penal bunker for drunkenness and for the loss of a purebred dog, which... the prisoners ate. "He was a good doggy [...]. Well-trained... with a pedigree... simply delicious!...,"18 attests the protagonist in the final scene of the story. Humorous accents of this type are hard to find in other works whose protagonists are the Soviet prisoners. ${ }^{19}$ The problem is related not only to the relative shortage of such texts, but also - and perhaps most importantly - to the blanks in our knowledge of the subject: thus far, the issue of the representation of the Soviet prisoners of war in Polish literature has not been sufficiently addressed. Admittedly, in texts such as Smoke over Birkenau or in Tadeusz Borowski's short stories the motif of the martyrdom of the Poles and the Jews is prominently visible; in contrast, the suffering of the Soviet POWs seems to have gone unnoticed, receiving little or no attention from the authors of such books.

And yet, it may be suspected that it was a Soviet POW who had managed to survive the hardest, initial period of imprisonment in Auschwitz that became a prototype of Ivan, one of the protagonists of Tadeusz Borowski's story "A Day at Harmenz," 20 a clever and ruthless prisoner, who, against all odds, does well in the camp. In his Anus Mundi, Kielar mentions "those who remained from the first Russian transport, the ones who had not been killed," as having "decent posts" 21 - and Borowski's Ivan seems to be one of them. In this context, the autobiography of Rudolf Hoess sheds even more light upon the fates of the Soviet soldiers held captive at Auschwitz:

Of more than 10,000 Russian prisoners of war who were to provide the main labor force for building the prisoner-of-war camp at Birkenau, only a few

${ }^{18}$ Ibidem, p. 67.

${ }_{19}$ That concerns works of fiction or non-fiction, both Polish-written and others.

20 T. Borowski: "A Day at Harmenz." In: This Way for the Gas, Ladies and Gentlemen. Selected and translated by B. VedDER. Introduction by J. KotT. Introduction translated by M. KANDEL. New York 1967, pp. 50-81.

${ }^{21}$ W. Kielar: Anus Mundi..., p. 191. 
hundred were still alive by the summer of 1942. Those who did remain were the best. [...] But I never got over the feeling that those who had survived had done so only at the expense of their comrades, because they were more ferocious and unscrupulous and generally "tougher." 22

The commandant of Auschwitz remains silent about the ruthlessness of the SS men. It is, however, poignantly illustrated on the pages of Marian Pankowski's book Z Auszwicu do Belsen (From Auschwitz to Belsen). ${ }^{23}$ Reminiscing on his stay in KL Gross-Rosen, the narrator of this fictionalized memoir recalls a "Russkiy," a youth about twenty years of age, chubby, in faded denim. Simon M., one of the thousands of the Red Army soldiers taken prisoner by Wehrmacht, shares the story of his former life in the camp with him:

They locked us up in those blocks [...]. They would toss slices of bread in through the windows above. We would all jump up to grab the bread... but after two or three days the strong ones took the power. Only they had the right to catch the falling slices - and whoever dared to protest, they would choke them? to death...

...every morning we had to remove the corpses of those who died during the night... On the first day I was lucky enough to intercept a slice, but only a half of it I managed to stuff in my mouth... when my neighbor tore the other half out of my hand. Day by day, it was getting worse... I didn't have enough strength to fight for bread. I was just lucky to have been standing right by the door. ${ }^{24}$

When the door suddenly opened, the SS man who entered saw Simon sobbing, and led him to one of the blocks still under construction: "This is how my first day began... because all there was before was but a stinking night..." 25 This is how Simon, a Soviet POW, became an (ordinary) concentration camp prisoner, and how his chances of survival significantly improved.

"Zagrycha" - Szmaglewska's humoresque alluded to before - is not the only work of fiction containing motifs related to the imprisoned Red Army soldiers. Another aspect of their tragic fate, which has not been mentioned thus far, involved the medical and pseudo-medical experiments to which they would be subjected. Erwin Krüger, a war criminal in hiding and the main protagonist of Jan Dobraczyński’s 1967 novel Doścignięty (Caught), mentions subjecting prisoners to hunger resistance tests in the experimental camp in Kulczyce. ${ }^{26}$

${ }^{22}$ R. Hoess: Commandant of Auschwitz. The Autobiography of Rudolf Hoess. Trans. C. FitzGibbon, with an introduction by Lord Russel of Liverpool. Cleveland-New York 1959, p. 136.

${ }^{23}$ M. Pankowski: $Z$ Auszwicu do Belsen. Przygody. Warszawa 2000.

${ }^{24}$ Ibidem, pp. 61-62.

${ }^{25}$ Ibidem, p. 63.

${ }^{26}$ This camp had no real-life, historical prototype. This said, camps of this type - camps strictly experimental in character - were called into existence at the begining of the 1930s by the Japanese. The central unit of this kind was located in Pingfang, near Harbin, in Manchuria. 
This is their image, as recalled from his memory:

Behind the bathhouse, the appearance of the camp somewhat changed. The series of small, adjacent pens came to an end, and the experimental fields were much larger here. Not a single barrack stood on the allotments extending to the left. It was just a huge square, naked, muddy, as if churned by pigs. In the center, there stood a solitary tree, or, actually, its skeleton: dry and stripped of the bark. On the ground, in small groups, people lay in lethargy. They were not wearing stripes, but were dressed in denim uniforms, ragged and dirty. Bare feet. Motionless. Apathy and stupor were painted on their still faces. ${ }^{27}$

These people were exposed to complete food deprivation for more than ten days; the "stronger" ones, as the commandant of the camp informs Krüger, were subjected to the cold tolerance test. ${ }^{28}$

Unlike it was in the case of Doścignięty, it is a mention of the fates of the Red Army POWs rather than a full-fledged motif that may be found in Aleksander Omiljanowicz's short story "Koniec kommanda śmierci" ("The end of the death kommando"). The story raises the issue of the mass executions of the prisoners of the POW camp in Bogusze in the Masurian Lakeland, among whom there also are Soviet officers. ${ }^{29}$ The text is worth referencing also on account of its author, whose twisted war biography uniquely corresponds with the complicated fates of the Soviet prisoners of war, which (as in the case of those who joined German auxiliary formations) were often morally ambiguous. It is worth recalling

In 1941, the unit received a number and was henceforth referred to as Unit 731. It is in one of its branches, one located in Canton, that experiments consisting in starving prisoners to death were carried out. See H. Gold: Unit 731: Testimony. Tokyo 1996, pp. $48 \mathrm{ff}$. Note that the new edition of the book was published under a different title: H. GolD: Japan's Infamous Unit 731. Firsthand Accounts of Japan's Wartime Human Experimentation Program. With a new foreword by Y. Totani. Tokyo-Singapore 2019). In Polish, the book was published as Jednostka 731. Okrutne eksperymenty w japońskich laboratoriach wojskowych. Relacje świadków. Trans. M. SzymoNIK. Kraków 2015. The Germans, in turn, would carry out experiments in the fields of nutrition and research on famine oedema in "regular" concentration camps. It was the latter area that Heinrich Berning specialized in. Using Soviet prisoners as his "research material," he starved several of them to death, meticulously documenting their agony. See E. KLEE: Auschwitz, die NS-Medizin und ihre Opfer. Frankfurt am Main 1997, pp. 179-189, 258-259; O. Schirg: "Als das UKE [Universitätsklinikums Eppendorf] unter die Nazis fiel" [review: H. van den Bussche: Die Hamburger Universitätsmedizin im Nationalsozialismus. Forschung-Lehre-Krankenversorgung. Berlin-Hamburg 2014] in Hamburger Abendblatt, https://www.abendblatt.de/hamburg/article133284418/Als-das-UKE-unter-die-Nazis-fiel.html [published 15.10.2014, accessed 28.04.2019].

27 J. Dobraczy Ński: Doścignięty. Warszawa 1967, p. 158.

${ }^{28} \mathrm{NB}$, the experiments on death caused by hypothermia were carried out in KL Dachau under the supervision of Ernst Holzlöhner. See E. KLEE: Auschwitz..., pp. 231-235.

29 A. Omiljanowicz: "Koniec kommanda śmierci." In: Sens życia. Warszawa 1971, pp. 68-80. For more information on the POW camp in Bogusze see Z. Lietz: Obozy jenieckie w Prusach Wschodnich 1939-1945. Warszawa 1982, pp. 104-106. 
that Omiljanowicz, a fiction writer authoring books dedicated to the themes of the Second World War and the "building of the people's government," served, from 1939, as a liaison for the Union of Armed Struggle (the underground army formed in Poland following the German invasion of the country at the onset of the war) and, after his arrest, became a prisoner of several Nazi camps. Having survived the war, in 1945 he became an officer of the (Polish) Department of Security, collaborating with the Soviet military counterintelligence (SMERSH) ${ }^{30}$ In 2005, Omiljanowicz was found guilty of the abuse of power, of torturing the interrogated members of independence organization, and other crimes. Consequently, he was sentenced to four and a half years in prison. He died in the State Penitentiary in Barczewo. ${ }^{31}$

More closely, however, we should study a text which granted the Soviet prisoner of war the role of the main protagonist. I am referring to Igor Newerly's novel Chłopiec $z$ Salskich Stepów (The boy from the Steppes of the Sal). The novel came into existence on commission of the Polish Radio and was first presented to the audiences as a series of radio shows. In 1948, the novel came out in print. ${ }^{32}$ In the years 1953-1999, with short breaks, it featured on the lists of mandatory reading for all types of schools: elementary, vocational, and secondary. ${ }^{33}$ Beginning with its 19th edition, the author would supplement the text with his afterword titled "Prawdziwe przygody autora i bohaterów tej powieści" (The true adventures of the author and the protagonists of this novel). It is from this afterword that we learn that the fates of Vladimir Lukitsh Dergachev have their source in the story of Vladimir Ilyich Degtyarev, recounted to Newerly on an April night of 1944 in Majdanek, where Degtyarev served as the principal of the hospital barrack. ${ }^{34}$ The writer himself admits that in reconstructing the events, he would often give free rein to his own imagination, coloring history with his own confabulations and yarn-spinning, with the view to creating a novel rather than a non-fictional account. ${ }^{35}$

As emphasized before, the protagonist of the novel is a Soviet prisoner of war. His life story, however, painted in vivid colors, transgresses the experience of imprisonment. Chłopiec $z$ Salskich Stepów, as an adventure story intended

${ }^{30}$ In Russian: Главное управление контрразведки «СМЕРШ» Народного комиссариата обороны (НКО) СССР. The acronym SMERSH is an abbreviation of two Russian words making up the slogan of the organization: "Смерть шпионам!” ("Death to the Spies!").

${ }^{31}$ See W. Cieśla: “Trzeci życiorys.” Rzeczpospolita 2005, no. 189, p. A13; T. Danilecki: "Dwaj literaci." Biuletyn Instytutu Pamięci Narodowej 2005, no. 12, pp. 28-39.

32 I. Newerly: Chłopiec z Salskich Stepów. Warszawa 1948. In 1997, the 24th edition of the novel was published. The most recent edition thus far is the one published in 2010.

${ }^{33}$ See A. Franaszek: Od Bieruta do Herlinga-Grudzińskiego. Wykaz lektur szkolnych w Polsce w latach 1946-1999. Warszawa 2006, p. 159.

${ }^{34}$ I. Newerly: "Prawdziwe przygody autora i bohaterów tej powieści." In: Chłopiec z Salskich Stepów. 19th ed. Warszawa 1974, p. 187.

${ }^{35}$ Ibidem, p. 201. 
for young adults, serves, above all, an educational function: it offers the readers a role model, one in agreement with the official policy of a socialist state, aiming to convey the image of the Soviet Union as a partner and a friend. Dergachev, whom the prisoners of Majdanek call "the Russian Doctor" and hold in the highest esteem, has the letter "P" sewn on his striped uniform, as he was captured as a Polish guerilla. He comes from a Cossack stanitsa, from the steppes of the river Sal. He talks about his tumultuous childhood, about his escape from home, about his stay in a juvenile reformatory, and about the education he got despite all obstacles, against the will of his father. He also talks about the war: about the defeat of his unit as a result of treason and about his imprisonment in the POW camp in Komorowo, which he himself dubs the Vernichtungslager, the extermination camp. He states that "compared to Komorowo, Majdanek is a resident hotel [...]. The processing of the human pulp was faster and more primitive in its forms." ${ }^{36}$ Further he adds: "one would often see things so monstrous that the idea that 'the human is no longer!' would often come to mind." ${ }^{37}$ The protagonist, however, never gave in to doubt, trusting the ideals of humanism. The foremost expression of his moral fiber, both in the POW camp and throughout his life, is the famous sentence from Maxim Gorky's play At the Bottom: "Human! That sounds proud!" ${ }^{38}$ Having escaped from the camp, he organizes a guerilla unit in the Kurpie region of Poland. Captured again by the Germans, he is deported to Majdanek. "Soon," declares the narrator, revealing further fates of Degtyarev and those of his own, "they have deported us from Majdanek to Auschwitz. [...] It was the Easter of 1944." ${ }^{39}$ From there, along with a group of prisoners, the protagonist is transported off to an unknown destination and vanishes without a trace. "Let then this story be his legacy,"40 writes the narrator at the end of his narrative.

Newerly met with Degtyarev in 1957. It was then that he got to know the post-war history of his protagonist. He quotes his words thus:

Upon my return, I did my very best [...] to contribute to the reconstruction... Some treated me ordinarily, without prejudice, others looked at me with a slant eye: they wanted to know exactly in what circumstances I was captured, how I behaved in the camps. ${ }^{41}$

Newerly adds that the Russian translation of Chłopiec z Salskich Stepów has largely contributed to the rehabilitation of Degtyarev as a former prisoner. Both

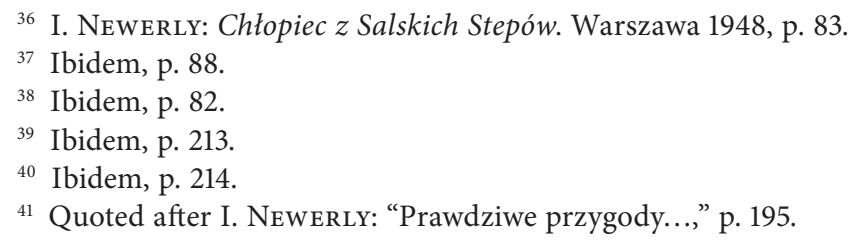


in his memoirs, titled Побеждая смерть (Conquering death), ${ }^{42}$ and in the literary representation of Newerly's, Degtyarev emerges as an unbreakable man, for whom imprisonment is not tantamount to defeat, but a stage in the struggle for liberty: a fight not only for his own freedom, but also for the freedom of man (humankind). And it is not accidentally that the figure of general Karbyshev, the prisoner of Stalag 324, of Majdanek, and of other camps, is invoked both in Побеждая смерть and in Dergachev's story. In Newerly's novel, Karbyshev finds his equivalent in the character of Karbasov, while in the Soviet and Russian memory of the Great Patriotic War, the general has proven to play the role of an "anti-Vlasov" of sorts. ${ }^{43}$

In turn, Andrey Vlasov himself is mentioned in Józef Mackiewicz's novel Kontra, which was published in exile in 1957, and therefore, essentially, was inaccessible to the readers in communist Poland. Among others, in his novel, the author recalls the general's death verdict and his execution by hanging in 1946 in Moscow. $^{44}$ Addressing the subject of treason which the democratic West committed with respect to the Cossacks - who, having fought against Bolshevism side by side with the Germans, were turned over to the Soviets in 1945 under the Yalta Agreement, and thereby were condemned to death or imprisonment in labor camps the writer also recalls the fates of the Soviet prisoners of war. He writes about the Germans murdering the captives in a camp near Częstochowa, describes how the Nazis formed auxiliary units of those who survived, and expands on the fears of those who, having managed to escape from the German captivity, were afraid that upon their return home they would be considered traitors. Hence, some of the Soviet captives were afraid to return to the ranks of the Red Army, others did not want to fight on the Bolshevik side or did not want to fight at all, while still others preferred to defect to Nazi Germany for political or ideological reasons.

Telling the story of the "Bolshevik counterrevolution in the years 1941-1944" and of the "authentic revolution of the poorest, the revolution of the masses," ${ }^{35}$ Mackiewicz undoubtedly idealizes the Cossacks, while ignoring numerous war crimes they committed while fighting on the German side. The only justification of his choices is the fact that the objective of his novel is to pass a just moral judgment on those who claim to be the defenders of freedom: the British and the Americans, who treat the nations of the East much like the Nazis did - as subhuman, or, at best, with a pronounced sense of superiority.

${ }_{42}$ В[ладимир] Дегтярев: Побеждая смерть. Ростов-на-Дону 1962. Polish translation: W. Diegtiariew: Zwyciężając śmierć. Trans. M. Klimkowski. Lublin 1970.

${ }^{43}$ See [NN]: Карбышев и Власов. Подвиг и предательство, „KM.RU,” http://www.km.ru/ news/karbyshev-i-vlasov-podvig-i-predatelstvo [published 18.02.2011, accessed 20.04.2019]; И. Шлионская: Генерал Карбышев: он не стал Власовым, https:/russian7.ru/post/karbyshev/ [published 14.10.2016, accessed 20.04.2019].

${ }^{44}$ J. Mackiewicz: Kontra. Paris 1957.

${ }^{45}$ Ibidem, p. 58. 
Having pointed to some of the realizations of the motif of the Soviet prisoners of war in Polish literature, I would now like to focus on a work which may safely be claimed to be both most well-known and the most outstanding, and, importantly, entirely devoted to the captive Red Army soldiers. It is therefore appropriate to treat it in greater detail than other texts. The work in question is the 1962 poem by Wisława Szymborska titled "Obóz głodowy pod Jasłem" ("The Hunger Camp at Jasło"). The poet has published the original version of the text in the Nowa Kultura, ${ }^{46}$ while its final version - which I quote below including cosmetic revisions (mostly in punctuation and font style), appeared in her book of poetry titled Sól (Salt).

Napisz to. Napisz. Zwykłym atramentem na zwykłym papierze: nie dano im jeść, wszyscy pomarli z głodu. Wszyscy. Ilu? To duza łąka. Ile trawy przypadło na jednego? Napisz: nie wiem. Historia zaokrągla szkielety do zera. Tysiąc i jeden to wciąż jeszcze tysiąc. Ten jeden, jakby go wcale nie było: płód urojony, kołyska próżna, elementarz otwarty dla nikogo, powietrze, które śmieje się, krzyczy i rośnie, schody dla pustki zbiegającej do ogrodu, miejsce niczyje w szeregu.

Jesteśmy na tej łące, gdzie stało się ciałem. A ona milczy jak kupiony świadek. W słońcu. Zielona. Tam opodal las do żucia drewna, do picia spod kory porcja widoku całodzienna, póki się nie oślepnie. W górze ptak, który po ustach przesuwał się cieniem pożywnych skrzydeł. Otwierały się szczęki, uderzał ząb o ząb.

Nocą na niebie błyskał sierp

i żął na śnione chleby.

Nadlatywały ręce z poczerniałych ikon, z pustymi kielichami w palcach.

$\mathrm{Na}$ rożnie kolczastego drutu chwiał się człowiek.

Śpiewano z ziemią w ustach. Śliczna pieśń o tym, że wojna trafia prosto $w$ serce.

Napisz, jaka tu cisza.

Tak. $^{47}$
Write it. Write. In ordinary ink on ordinary paper: they were given no food, they all died of hunger. All. How many? It's a big meadow. How much grass for each one? Write: I don't know. History counts its skeletons in round numbers. A thousand and one remains a thousand, as though the one had never existed: an imaginary embryo, an empty radle, an $\mathrm{ABC}$ never read, air that laughs, cries, grows, emptiness running down steps toward the garden, nobody's place in the line.

We stand in the meadow where it became flesh, and the meadow is silent as a false witness.

Sunny. Green. Nearby, a forest with wood for chewing and water under the barkevery day a full ration of the view until you go blind. Overhead, a birdthe shadow of its life-giving wings brushed their lips. Their jaws opened. Teeth clacked against teeth.

At night, the sickle moon shone in the sky and reaped wheat for their bread.

Hands came floating from blackened icons, empty cups in their fingers.

On a spit of barbed wire,

a man was turning.

They sang with their mouths full of earth. A lovely song of how war strikes straight at the heart. Write: how silent.

Yes.

46 W. Szymborska: “Obóz głodowy pod Jasłem.” Nowa Kultura 1962, no. 5, p. 1.

47 W. Szy mborska: “Obóz głodowy pod Jasłem.” In: Sól. Warszawa 1962, pp. 25-26. The poem has been translated into English by G. DrABIK, A. Flint, see: https://www.poemhunter.com/poem 
My claim that we deal with a well-known poem partly relies upon Wisława Szymborska's reputation as a Nobel Prize winner (which, in itself, is an important factor motivating readers to take up the interpretation of her poetry), but it is especially the fact that in the years 1969-1988 the poem used to be on the mandatory reading list for Polish high school students that supports my position. ${ }^{48}$ In this context, the almost complete absence of its interpretations available in print comes as a surprise, especially when one bears in mind that other poems Szymborska dedicated to genocide, especially to the Shoah, received a lot of critical attention. Good examples of such poems are her "Transport Żydów 1943" (The transport of Jews 1943) and "Jeszcze" (Still). ${ }^{49}$ The only publication entirely

/hunger-camp-at-jaslo/ [accessed 10.01.2020] (see my comments on the translation at the end of this footnote). The most recent press reprint of the poem was published in 1988 in the Resovian periodical Nowiny (more specifically, it appeared in an insert to the magazine, titled Widnokrag, no. 17, p. 1). The poem continues to be included in volumes of Szymborska's selected poetry, yet, not infrequently, the reprints contain errors. Unfortunately, such errors flaw two important editions of the Nobel Prize winner's work. The first is the volume Wiersze wybrane (Selection and arrangement by the author. A new, extended ed. Kraków 2012, pp. 80-81) edited by R. KRYNICKI; the second one, trustingly relying upon the authority of the former, is Wybór poezji, ed. W. LigęzA and with his introduction. Wrocław 2016, pp. 94-95. I wish to point out only two, albeit glaring, errors, which may impact the interpretation of the work (below, phrases from the Sól collection are juxtaposed with those present in both poetry selections): "schody dla pustki zbiegającej do ogrodu" ["emptiness running down steps toward the garden"] vs. "schody do pustki zbiegającej do ogrodu" ["stairs towards the emptiness running into the garden"]; "porcja widoku całodzienna" ["every day a full ration of the view"] vs. "porcja widoku codzienna" ["a daily ration of the view"]. The quoted English version of the poem appears to lean towards the version included in the two poetry selections discussed above. Importantly, however, two phrases call for particular attention: the Polish phrase "pożywne skrzydła" ["nutritious wings"] has been translated as "life-giving wings," while the verses "Nocą na niebie błyskał sierp / i żął na śnione chleby" ["At night, the sickle moon shone in the sky / and reaped wheat for the dreamt bread] is translated as "At night, the sickle moon shone in the sky / and reaped wheat for their bread." The consequences of these decisions of the translators need to be taken into account while analyzing the poem in English.

${ }^{48}$ See A. Franaszek: Od Bieruta do Herlinga-Grudzińskiego..., p. 235. The poem was published, among others, in: R. MATUszewski (ed.): Wiersze polskich poetów współczesnych. Wybór. Książka pomocnicza dla uczniów klas IV i V szkót średnich. Warszawa 1976, pp. 172-173. "The Hunger Camp...” was translated into English, Belorussian, Bulgarian, Czech, Latvian, German, Russian, and Hungarian.

${ }^{49}$ W. Szymborska: “Transport Żydów 1943.” Dziennik Literacki 1948, no. 17, p. 2; W. SzymBorska: "Jeszcze.” In: Wołanie do Yeti. Kraków 1957, pp. 37-38. Interpretations: M. GŁowiŃSKI: Wisławy Szymborskiej ballada o Zagładzie [concerning both poems]. In: M. KaLINowsKa, E. KIśLAK (eds.): Lustra historii. Rozprawy i eseje ofiarowane Profesor Marii Żmigrodzkiej z okazji pięćdziesięciolecia pracy naukowej. Warszawa 1998, pp. 183-189; T. CieśLAK: "O Holokauście. Jeszcze Wisławy Szymborskiej.” In: W poszukiwaniu ostatecznej tajemnicy. Szkice o polskiej literaturze XX wieku i najnowszej. Łódź 2009, pp. 113-123; J. RoszaK: "Wstań, imię. Jeszcze Wisławy Szymborskiej.” Polonistyka 2012, no. 11, p. 43-45; K. KuczyńsKa-Koschany: “Trzy wiersze najważniejsze: Szymborska” [addressing, among others, the poem “Jeszcze”/“Still”]. In: „Bсе nоэты жиды". Antytotalitarne gesty poetyckie i kreacyjne wobec Zagłady oraz innych doświadczeń granicznych. Poznań 2013, pp. 275-283. 
dedicated to "The Hunger Camp..." that I have come across thus far is an article on teaching literature at school by Michał Świerz. However, next to excellent observations and adroit reflections, the article also contains remarks that seem to be off the mark, or imprecise. For instance, the author suggests that the poet/ lyrical I "as a tourist stopped at the camp's drill ground," 50 when no mention of such a location can be found in the poem. Somewhat further, Swierz makes a reference to "people" imprisoned in the camp, but does not specify who these people are, despite his obvious extra-textual awareness, to which the following sentence clearly testifies: "Today the place bustles with life: on the site of the former camp, there is a memorial school." ${ }^{52}$ Because the author does not disclose any further details concerning the title object of the poem, one should add that four years after the Polish State Millennium Memorial School was erected in 1964 on the site of the former camp (or, de facto, three camps, which issue shall be discussed further in the text) in Szebnie near Jasło, an obelisk was unveiled. It featured a commemorative plaque reading: "HERE, IN THE YEARS 1941-1944, CAPTIVES OF SOVIET, POLISH, AND OTHER NATIONALITIES SUFFERED AND DIED IN THE NAZI CAMP. SEPTEMBER 1968. ${ }^{.53}$ A question then arises if those who "died of hunger" in Szymborska's poem were all of the ethnicities mentioned in the plaque - the Soviets, the Poles and "other nationalities," among whom, as we know from elsewhere, were also Jews, murdered in a forest nearby.

In Szymborska's poetry dedicated to the Shoah it is easy to determine the ethnicity of particular characters. In "Transport Żydów 1943" it is the title that specifies the group; in "Jeszcze," for instance, it is the first names - Nathan, Isaac, Sarah, Aaron, David - that disperse possible doubt. Yet, in the case of "The Hunger Camp..." such an identification turns out to be more difficult. It is hard to unambiguously determine if the authors of the critical texts I quote next chose to speak of those who "died of hunger" using generic terms (such as "people" or "victims"), or to determine the ethnicity of the group only too specifically (as "Jews"), out of ignorance, or whether their gestures were deliberate - each a literary device intended to blur (for some reason or other) the identity of the dead. Let us consider a few statements located in the spectrum between the two poles: universalization, on the one hand, and, on the other - precise identification of the ethnicity of those starved to death.

${ }^{50}$ M. Świenz: "Podmiot liryczny w wierszu Szymborskiej Obóz głodowy pod Jasłem." Polonistyka 1983 , no. 4, p. 258.

${ }^{51}$ Ibidem, p. 259.

52 Ibidem.

${ }^{53}$ See M. Wieliczko: Jasielskie w latach drugiej wojny światowej. Warszawa 1974, p. 179; S. Zabierowski: Szebnie. Dzieje obozów hitlerowskich. Rzeszów 1985, p. 183; Z. Macek: Hitlerowski obóz pracy przymusowej w Szebniach. Jasło 2013, pp. 227-233, 268; [NN]: Historia szkolnictwa $w$ Szebniach, http://www.zsszebnie.szkolnastrona.pl/index.php?c=article\&id=1 [accessed 3.05.2019]. 
Possibly, it was under the influence of Ryszard Matuszewski's interpretation of "The Hunger Camp..." that the present day "standard" reading of the poem in question has been shaped. In his 1976 compendium of literature for high school students, Matuszewski - an authority on Szymborska's oeuvre and a recognized author of school course books - writes thus:

"The Hunger Camp at Jasło" is a test of poetic imagination in terms of one's capability of realizing what it was that the prisoners condemned by the Nazis to the death from starvation experienced. The consistent uniformity of the metaphors is a deliberate stylistic device, serving, throughout the poem, the sole purpose of the concretization of the horrifying sensation of hunger (in the imagination of the captives, the forest provides "wood for chewing and water under the bark," the bird "brushes their lips" with "the shadow of its lifegiving" [or, as in the Polish original, "nutritious"] "w4 "wings," the sickle of the moon brings harvest to mind, and thereby, makes one dream of bread, etc.). ${ }^{55}$

Alas, for reasons unknown, Matuszewski does not specify who the prisoners evoked in the poem are. Importantly, the same interpretation of Szymborska's poem can be found in the textbooks he published in subsequent years, and a similar, albeit somewhat abbreviated analysis is present in his 1992 book on Polish literature of the period 1939-1991, which the publisher recommends to "all senior year high school students." ${ }^{56}$ Equally general, universalizing interpretation of the poem is offered by Astra Piotrovska in her monograph Художественные искания современной польской литературы (The artistic explorations of contemporary Polish literature), published in the Soviet Union in 1979: "The [...] poem is dedicated to the martyrdom of thousands of prisoners of the Nazi concentration camp." ${ }^{57}$ Similar universalizing readings can be seen in works by Polish literary scholars published after 1989. For instance, in his study dedicated to Szymborska's poetry Jan Majda remarks thus: "It was through Dante's Inferno incarnate that the [...] prisoners of the camp at Jasło

${ }^{54}$ See the analysis of the English translation of the poem in footnote 47 of this text.

${ }^{55}$ R. Matuszewski: Polska literatura współczesna. Podręcznik pomocniczy dla klasy IV liceum ogólnokształcacego oraz dla klasy V techników i liceów zawodowych. Warszawa 1976, p. 243. Szymborska's poem has been published in the anthology Wiersze polskich poetów współczesnych (pp. 172-173), which was intended as a reader supplementing the course book.

${ }^{56}$ See R. Matuszewski: Polska literatura wspótczesna. Podręcznik pomocniczy dla klasy IV liceum ogólnokształcacego oraz dla klasy $V$ techników i liceów zawodowych. 6th revised ed. Warszawa 1981, p. 273; R. Matuszewski: Literatura współczesna dla kl. IV lub V szkoły średniej. 13th revised ed. Warszawa 1988, p. 223; R. MAtuszewski: Literatura polska 1939-1991. Warszawa 1992, p. 291 (the publisher's recommendation is located on page two of this edition).

57 "Стихотворение [...] посвящено мученической смерти тысяч узников фашистского концлагеря” (А[стра] Пиотровская, Художественные искания современной польской титературы. Проза и поэзия 60-70-х годов. Москва 1979, р. 239). 
lived before they were starved to death by the Hitlerites." ${ }^{58}$ Likewise, in her 2012 article, Joanna Roszak mentions the poem as dedicated "to the memory of the prisoners of war." 59 Some scholars, especially western academics, would qualify these prisoners (whether military or civilian) as Poles or Jews. For instance, Hans Joachim Nauschütz situates the poem in the contexts of a concentration camp in which "many thousands of Poles perished" and of a Jewish ghetto, ${ }^{60}$ yet he fails to mention the Soviet prisoners of war. Allan Reid analyzes "The Hunger Camp..." among three of Szymborska's poems dedicated to the Holocaust, which he understands as equivalent to the Shoah, the extermination of the Jews. ${ }^{61}$

Historians, who did not have much trouble identifying who was imprisoned and who was starving to death in the camp (or, actually, camps) at Jasło, have demonstrated more precision than literary scholars. In his 1974 monograph regarding the Jasło region during the Second World War, Mieczysław Wieliczko remarks that "In her 'Hunger Camp at Jasło,' Wisława Szymborska erected a poetic monument to the Soviet prisoners of war, thus paying tribute to their shadows." ${ }^{2}$ An interesting case is that of Stanisław Zabierowski, who purposefully and eloquently - included Szymborska's poem as an epigraph to the chapter on "Soviet POW Camps in Szebnie (1941-1942 and 1944)"63 in his book dedicated to the history and transformations of the camps run in Szebnie near Jasło, which was published eleven years after Wieliczko's monograph. The second chapter of Zabierowski's book is entitled "Forced Labor Camp in Szebnie (1943-1944)." In the book, the author focuses upon three German camps, whose prisoners were detained in barracks surrounded by barbed wire, which were originally built to accommodate the needs of the Wehrmacht in 1940 in the village of Szebnie, about ten kilometers away from Jasło. The first of the three camps is the POW camp for the Red Army soldiers (in operation between October 1941 and September 1942); the second one is the forced labor camp (functioning between March 1943 and February 1944); the third is another "Lager" for the Soviet prisoners of war (operating between March and August 1944).

In the first of them, the sub-camp of the main camp No. 327 (located in Olchowce) bearing the official name of Stammlager 327 Lager Szebnie, six to seven thousand Soviet prisoners of war were imprisoned, most of whom initially stayed

${ }^{58}$ J. Majda: Świat poetycki Wisławy Szymborskiej. Kraków 1996, p. 17.

59 J. Roszak: "Wezwałem cię po numerze. 172364, 119198, 132434 i inni." Przestrzenie Teorii 2012, no. 18, p. 68.

${ }^{60}$ H.J. Nauschütz: "Na sympozjum w Oświęcimiu w październiku 1997 r.” Trans. J. ZAcharska. In: J. Papuzińska, G. Leszczyński (eds.): Dzieciństwo i sacrum. Studia i szkice literackie. Warszawa 1998, pp. 61-62.

${ }^{61}$ A. ReID: "Szymborska Wisława." In: T. Riggs (ed.): Reference Guide to Holocaust Literature. With introduction by James E. Young. Detroit 2002, p. 313. The two other poems are "Jeszcze" ("Still") and "Pierwsza fotografia Hitlera" ("Hitler's First Photo").

${ }^{62}$ M. Wieliczko: Jasielskie w latach drugiej wojny światowej..., p. 173.

${ }^{63}$ S. Zabierowski: Szebnie..., p. 21. 
(vegetated) in the open air. ${ }^{64}$ Gradually, the camp expanded: the capacity of barracks increased to ten thousand people. It is estimated that four to five thousand Red Army soldiers perished there. ${ }^{65}$ Although formally Stammlager 327 was a POW camp, in fact it functioned as a death camp. According to Mieczysław Wieliczko:

It was a site of planned and systematic extermination - extermination based on the most primitive methods, a site of the destruction of thousands, and the only difference between this form of the camp and the extermination camp lies in the fact that the corpses of the deceased were not burned and their mass graves have survived to this day as traces - and documents - of the crime. ${ }^{66}$

After the liquidation of the prisoner-of-war camp, the Germans organized a forced labor camp (Der SS und Polizeiführer in Distrikt Krakau, Zwangsarbeiterlager Szebnie) in the same place. The camp was intended for Jews (initially the only group of prisoners), Poles, Gypsies, Lemkos, Ukrainians, Belarussians, and Russians (the latter were mostly fugitives from their posts of forced labor in the Reich). The Jews imprisoned in Szebnie were detained with the intention of their extermination. One group of the Jewish prisoners was exterminated in the forest in Dobrucowa immediately upon arrival; many others were sent to the gas chambers of Auschwitz a few months later, on November 4th, 1943. The remaining five hundred, like the first group, were mass executed in Dobrucowa. In total, over 1,200 Jews and many Poles, whose exact number historians find difficult to estimate, were murdered in the Dobrucowa forest. ${ }^{67}$ Among the guards of the forced labor camp were the former prisoners of war of the former Stalag. They participated in mass executions of the Jews; several of them were later expelled from the unit and incarcerated in the camp as ordinary prisoners. ${ }^{68}$

Immediately after the cessation of the operations of the forced labor camp, several thousand Soviet prisoners of war were incarcerated in the same barracks. This second prisoner-of-war camp was attributed the number 325. This time, prisoners were treated better than in the years 1941-1942, and some guards spoke Russian. ${ }^{69}$

Thus, in fact, three, not one, Nazi camps operated at Jasło, of which the hunger camp was the first. This does not mean that in the other two the prisoners were well fed: of course, they were starving, but in the case of the camp

${ }^{64}$ See Z. МАсек: Hitlerowski obóz pracy przymusowej..., p. 15.

${ }^{65}$ See S. Zabierowski: Szebnie..., pp. 29, 42, 174-175.

${ }^{66}$ M.J. Wieliczko: "Obóz wyniszczenia w Szebniach w latach 1941-1944." Rocznik Przemyski 1970, vol. 13/14, p. 249.

${ }^{67}$ Ibidem, pp. 64, 69, 76, 100, 122, 160-166.

${ }^{68}$ Ibidem, pp. 100-101.

${ }^{69}$ Ibidem, pp. 43-46. 
number 327 starvation was a deliberate and direct instrument of murder. The first transport, numbering about 2,000 prisoners, arrived in Szebnie on October 9th, $1941 .^{70}$ The villagers who observed the prisoners being rushed into the unfinished camp recalled that "their appearance was regrettable. The prisoners, ragged, some without footwear, were so starved that they ate fruit cores they found lying on the road." ${ }^{71}$ Here is what Stanisław Zabierowski writes about the treatment of the prisoners of war already incarcerated in the Stalag:

Following the general guidelines, the camp command focused all its activities on the rapid elimination of prisoners.

The first method to destroy them was to constantly starve them. Prisoners received measly portions of food, mainly in the form of a watery soup made from rotten potatoes and cabbage. The hunger in the camp was so great that the prisoners constantly gathered at the fence and begged those passing or driving by for food. The inhabitants of Szebnie, who would occasionally enter the camp to perform work commissioned by the Germans, state that at the time of meals the prisoners would literally throw themselves on the food, despite the fact that such behaviors caused severe repressions on the part of the guards. They were so starved that they ate raw potatoes and fodder beet, which they managed to get from the people of Szebnie. The camp guards mocked the prisoners' hunger; they would throw pieces of bread at clusters of standing or sitting prisoners, and when the starved people fought for every morsel, they would laugh at the spectacle.

The Germans banned the civilian population from any contact with the prisoners. They even forbade the locals to look towards the camp. In this way, they hoped to prevent illegal food delivery. The prisoners were supposed to starve to death. Despite these measures, the local people used every opportunity that presented itself to help the captives. ${ }^{72}$

Complementing Zabierowski's account, Zofia Macek writes that within the confines of the camp

not a single plant remained: everything, to the very last straw and leaf, was eaten by the prisoners. The inhabitants of the village recall that also around the fence, as far as a human arm could reach, the grass was thoroughly plucked.

The prisoners-of-war camp remains in the memories of the [Szebnie] residents as an unspeakable nightmare. Throughout the day and night, terrible screams came out of the camp, the uproar of thousands of starved, cold and emaciated beings. ${ }^{73}$

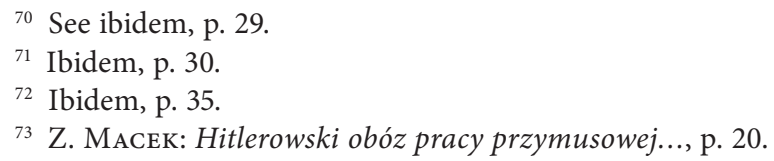


One of the inhabitants testified thus: "In the camp, I saw the prisoners dragging the corpses of their dead fellows out of the barracks and pulling them to the square... I saw that the bodies of these prisoners were like skeletons." ${ }^{\prime 4}$ The Soviet prisoners of war would also die in Szebnie as a result of severe cold, beating, hard work (during the expansion of the camp itself and in the oil refinery in Niegłowice), atrocious sanitary conditions, diseases (especially the epidemics of dysentery and typhus). Their corpses were buried in Doły Bierowskie, the ravines at the outskirts of the village of Bierówka. ${ }^{75}$

Admittedly, the more inquisitive coursebook writers and literary scholars, such as Barbara Kryda or Aneta Wiatr (who may or may not have consulted some of the historical studies cited here), have not failed to point out that the prisoners of the "hunger camp" were the Soviet prisoners of war. ${ }^{76}$ However, some ambiguities related to Szymborska's poignant poem still remain: firstly, they concern the genesis of the work, and secondly - its far-from-obvious, veiled content. Let us begin with the genesis of the work.

In her report about the congress of former prisoners of the forced labor camp in Szebnie in 1979, Zofia Macek recalls that the former inmate of this camp, and then of KL Plaszow, Danuta Olszowska-Konieczny

recounted her experiences to her close friend, Wisława Szymborska, already a well-known poet at the time, suggesting the following: "Write it. Write. In ordinary ink on ordinary paper: they were given no food, they all died of hunger. All."

Wisława Szymborska then wrote the poem "The Hunger Camp at Jasło," $[\ldots]$ in memoriam of the victims of the Hitlerite camps in Szebnie. ${ }^{77}$

Further on, Macek specifies that the poem "reflects the experiences of the Soviet prisoners dying of starvation." ${ }^{78}$ A somewhat different genesis of the poem is presented by Grzegorz Motyka:

74 Quoted after S. Zabierowski: Szebnie..., p. 38.

75 See ibidem, pp. 36-43.

${ }^{76}$ Krajobraz poezji polskiej. Antologia. Selection and introduction by B. KRYDA. 3rd revised ed. Warszawa 1992, p. 353 (footnote 1); A. Wiatr: Syzyf w piekle współczesności. Rzecz o Wisławie Szymborskiej. Warszawa 1996, p. 68.

77 Z. МАсек: Hitlerowski obóz pracy przymusowej..., p. 232. It is worth noting that, following in Szymborska's footsteps, the author of the book wrote a poem dedicated to the Soviet prisoners of war dying in Szebnie. The poem, titled "Jeńcom głodem i zimnem uśpionym" (To prisoners put to sleep with hunger and cold) is an unquestionable case of graphomania, as the following passages demonstrate: "Przybyli z bardzo daleka, / tu zimny lagier ich czekał. [...] / Nikt nie ujął się za nimi, / Głodowi pozostawieni. / Czasem głos z góry przyleci / Ach, śpijcie spokojnie dzieci. / [...] Tylko ptaki na drzewach / Tęskną dumkę będą śpiewać” (in: Z. MACEk: Hitlerowski obóz pracy przymusowej..., p. 30).

${ }_{78}$ Z. МАСЕк: Hitlerowski obóz pracy przymusowej..., p. 232. 
After her visit to the [...] cemetery in Szebnie, moved by the anonymity of the graves of Red Army soldiers, [...] Wisława Szymborska pointed to the limitations of the work of historians in her poignant poem: "It's a big meadow. How much grass for each one? [...] History counts its skeletons in round numbers. A thousand and one remains a thousand."79

The author does not support the claim that the poet actually visited Szebnie with any evidence. He may have succumbed to the poem's suggestibility, its clearly outlined lyrical situation ("We are in this meadow") and the empathy of the speaking "I." In any case, I was unable to find any information about Szymborska's visit to the site. In such a situation, all one can do is speculate on what the poet did - or, more probably, could - see there, if such a visit indeed ever took place.

The construction of the school on the site of the former camp began in 1963. Before the work started, the area was thickly overgrown with shrubbery. In turn, the area in Bierówka, where the mass graves of Soviet prisoners of war from the Szebnie camp were located, was tidied up in the years 1961-1965. Semicircular, grass-seeded terraces were created there, and a monument was erected. The plaque of the monument, reading: "IN MEMORY OF THE VICTIMS OF FASCism / MURdered / IN THE SZEbnie CAMp / IN THE YeARS 1942-1944 / on the 2oth anniversary of the People's Republic of Poland," featured a red star, which specified the identity of (some of) the victims (it is worth noting that the initial date in the inscription was inadequate). Today, the inscription features the dates "1942-1945," and the formula "ON THE 2oth ANNIVERSARY OF The People's Republic of Poland” has been removed (now, as can be seen, the final date is inadequate). The unveiling ceremony took place in 1962, the very year in which Szymborska's poem was first published. Its publication may have played a role - perhaps even a key role - in the process leading to the erection of the monument.

However, it is the poet herself, as the minister of meanings, who remains the source of uncertainty regarding the dedicatees of her unique epitaph, "The Hunger Camp at Jasło." This is not her only work dedicated to the victims of war. In her debut poem titled "Szukam słowa" (I am looking for a word) (1945), she included a stanza "corresponding" to the "Hunger Camp...": "Chcę, niech jedno to słowo / krwią będzie nasycone, / niechaj jak mury kaźni / pomieści w sobie każdą mogiłę zbiorową" ("I want it, I want this one word / to be sated with blood / let it hold every mass grave / like the death block walls"). ${ }^{80}$ The poet withdrew from this declaration quite quickly, focusing on specific victims, among whom the heroes of the title poem from the volume Dlatego żyjemy (This is why we

\footnotetext{
${ }^{79}$ G. Мотүка: "Tragedia jeńców sowieckich...," p. 33.

${ }^{80}$ W. Szymborska: “Szukam słowa." Dziennik Polski 1945, no. 39, supplement Walka, no. 3,
} p. 3. 
live) - Soviet soldiers who fell defending Stalingrad, staunch communists, exemplary heroes - were particularly well visible. Each of them was mentioned by name, and each received a separate epitaph. ${ }^{81}$ This rhetorical device served the purpose of legitimizing the role models presented in the poem - the heroes, who put their lives on the line for the grand idea, in which, ironically, an individual is utterly insignificant. Having given up propagating communism through poetry around the time of the Polish Thaw of October 1956, writing "Hunger Camp...," Szymborska demonstrated both restraint and prudence: aware of the pitfalls of an openly declarative position, she was silent about the identity of those starved to death, or - more precisely - she veiled it.

In 1962, the historical context indicated in the title of her poem was far from obvious, since, at the time, hardly anyone had heard about the (unspecified) camp at Jasło. After this date, until Zabierowski's book was published, relatively little changed. The ceremonies at the Bierówka cemetery were local in character. It was mostly historians and the local community who knew about the camps in Szebnie, and, in all probability, such is the case today. However, next to the title, the poem offers other hints suggesting that its protagonists are the Soviet prisoners of war. The first of such hints may be seen in the line: "Hands came floating from blackened icons," which indicates the cultural background of those who were starved to death. In Poland, the icon is associated with Orthodoxy, in particular with Eastern Slavs. Thereby, image of the icon evokes associations with Russians, Ukrainians, and Belarusians living in the Soviet Union at the time. They made up the bulk of the Red Army, and probably they made up the majority of the inmates of Stalag 327. The second suggestion is the motif of the sickle - shining in the sky, and reaping wheat for dreamt-of bread - which evokes the emblem of the Soviet Union.

The lesson of socialist realism taught Szymborska caution, but even that did not prevent "The Hunger Camp at Jasło" from being exorcised from the school reading list, which happened in 1988. At the end of the 1980s, other prisoners of war - the Polish soldiers mass murdered by the Soviets in Katyn - came to the forefront of the Polish historical memory; they were soon to start playing a significant role in the historical politics of the Polish state. ${ }^{82}$

The above notwithstanding, the poet continued to include this poem in her books of selected poetry, which, undoubtedly, was the right choice. Artistically powerful and, at the same time, poignant, the poem bears no traces of propaganda: it is rather a testimony to a commitment made in the name of the individual, the human, and not the (political) idea. This stance finds yet another expression in the

${ }^{81}$ W. Szymborska: “Dlatego żyjemy.” In: Dlatego żyjemy. Warszawa 1952, pp. 5-7.

${ }^{82}$ See P. Kowal (in collaboration with G. So£tysiak): "Katyń w relacjach PRL-ZSRR w latach 1985-1989." Polski Przeglad Dyplomatyczny 2010, no. 2, pp. 145-158; W. WAsilewski: "Pamięć Katynia. Działania opozycji." Biuletyn Instytutu Pamięci Narodowej 2009, no. 5/6, pp. 60-69. 
title poem from Szymborska's book of poetry Wielka liczba (A great number), in which we read the following declaration: "[...] moja wyobraźnia jest jak była. / Źle sobie radzi z wielkimi liczbami. / Ciągle ją jeszcze wzrusza poszczególność" ("my imagination remains as it was. / It clumsily copes with great numbers. / Still it is sensitive to the particular"). ${ }^{83}$ Unfortunately, in the case of the Soviet prisoners of war, the "particularity" - the uniqueness of an individual - remains insufficiently emphasized, not only in Russia, but also in other countries of the former Soviet Union and in Poland.

In conclusion, let us add that the formula "the Soviet prisoners of war," as precise as it may seem, not only fails to adequately point to the complex and tragic fates of the captive Red Army soldiers, but also blurs their identities. As an example, it is worth noting that among the Red Army soldiers captured, incarcerated, and murdered by the Germans there were men and women representing numerous nations of Europe and Asia, including Poles, who mostly came from the territories of the Second Republic of Poland seized by the Soviets in 1939, and who - under the Soviet occupation - were forced to adopt the citizenship of the USSR. They died in both prisoner-of-war and concentration camps, including the Stalag in Chełm and in KL Auschwitz-Birkenau. ${ }^{84}$ It is rarely remembered because too few people are aware of these facts. And much knowledge, not only about the Soviet prisoners of war, may be gained both from literature and owing to literature. Through the use of allusion, suggestion, or (eloquent) silence, literature occasionally divulges facts, which the historical politics prefers to hush down, or blatantly gags.

\section{Bibliography}

[Borowski T.]: Dzień na Harmenzach. In: J. Nel-Siedlecki, K. Olszewski, T. BoROWski: Byliśmy w Oświęcimiu. [München 1946], pp. 68-93.

Borowski T.: "A Day at Harmenz." In: This Way for the Gas, Ladies and Gentlemen. Selected and translated by B. VEDDER. Introduction by J. КотT. Introduction translated by M. KANDEL. New York 1967, pp. 50-81.

Cieśla W.: “Trzeci życiorys.” Rzeczpospolita 2005, no. 189, p. A13.

${ }^{83}$ W. SzymbоRSKa: “Wielka liczba." In: Wielka liczba. Warszawa 1976, p. 5; W. SzyмвоRsкA: "A Great Number." Trans. C. MıŁosz, http://www.ronnowpoetry.com/contents/szymborska/Gre atNumber.html [accessed 2.03.2020].

${ }^{84}$ See A. Ryвak: "Losy jeńców sowieckich w Stalagu 319 w Chełmie...," p. 36; A. Cyra: "Polacy wśród jeńców sowieckich w KL Auschwitz.” In: J. FARYś, T. SikorsKi, P. SŁowiński (eds.): Wrzesień 1939 roku. Geneza II wojny światowej w polskiej perspektywie. Vol. 2 (Wojsko. Wojna. Jeniectwo). Gorzów Wielkopolski 2010, pp. 213-221. 
Cieślak T.: “O Holokauście. Jeszcze Wisławy Szymborskiej.” In: W poszukiwaniu ostatecznej tajemnicy. Szkice o polskiej literaturze XX wieku i najnowszej. Łódź 2009, pp. 113-123.

Cyra A.: "Polacy wśród jeńców sowieckich w KL Auschwitz." In: J. FARYś, T. SiKorski, P. SŁOWIŃski (eds.): Wrzesień 1939 roku. Geneza II wojny światowej w polskiej perspektywie. Vol. 2 (Wojsko. Wojna. Jeniectwo). Gorzów Wielkopolski 2010, pp. 213-221.

Czech D.: "Kalendarz najważniejszych wydarzeń z dziejów KL Auschwitz." In: W. DŁugoBORSKi, F. Piper (eds.): Auschwitz 1940-1945. Węzłowe zagadnienia z dziejów obozu. Vol. 5. Oświęcim 1995, pp. 73-151.

Danilecki T.: “Dwaj literaci." Biuletyn Instytutu Pamięci Narodowej 2005, no. 12, pp. 28-39.

Дегтярев В[ладимир]: Побеждая смерть. Ростов-на-Дону 1962.

Diegtiariew W.: Zwyciężając śmierć. Trans. M. KLimkowski. Lublin 1970.

Dobraczý́ski J.: Doścignięty. Warszawa 1967.

Franaszek A.: Od Bieruta do Herlinga-Grudzińskiego. Wykaz lektur szkolnych w Polsce w latach 1946-1999. Warszawa 2006.

GŁowiński M.: "Wisławy Szymborskiej ballada o Zagładzie.” In: M. KalinowsKa, E. KIślak (eds.): Lustra historii. Rozprawy i eseje ofiarowane Profesor Marii Żmigrodzkiej z okazji pięćdziesięciolecia pracy naukowej. Warszawa 1998, pp. 183-189.

Gold H.: Japan's Infamous Unit 731. Firsthand Accounts of Japan's Wartime Human Experimentation Program. With a new foreword by Y. Totani. Tokyo-Singapore 2019.

Gold H.: Jednostka 731. Okrutne eksperymenty w japońskich laboratoriach wojskowych. Relacje świadków. Trans. M. Szymoniк. Kraków 2015.

Gold H.: Unit 731. Testimony. Tokyo 1996.

[NN]: Historia szkolnictwa w Szebniach, http://www.zsszebnie.szkolnastrona.pl/index .php?c=article\&id=1 [accessed 3.05.2019].

Hoess R.: Commandant of Auschwitz. The Autobiography of Rudolf Hoess. Trans. C. FitzGibbon, with an introduction by Lord Russel of Liverpool. ClevelandNew York 1959.

[NN]: Карбышев и Власов. Подвиг и предательство. „KM.RU,” http://www.km.ru/news /karbyshev-i-vlasov-podvig-i-predatelstvo [published 18.02.2011, accessed 20.04.2019].

Kielar W.: Anus Mundi. 1,500 Days in Auschwitz/Birkenau. Trans. S. Flatauer. New York 1980.

Kielar W.: Anus mundi. Wspomnienia oświęcimskie. Kraków 1972.

KLEE E.: Auschwitz, die NS-Medizin und ihre Opfer. Frankfurt am Main 1997.

Kowal P. (in collaboration with G. SoŁtysiak): "Katyń w relacjach PRL-ZSRR w latach 1985-1989." Polski Przegląd Dyplomatyczny 2010, no. 2, pp. 145-158.

Krajobraz poezji polskiej. Antologia. [Selection and introduction by] B. KRYDA. 3rd revised ed. Warszawa 1992.

Kranz T.: "Ewidencja zgonów i śmiertelność więźniów KL Lublin.” Zeszyty Majdanka 2005, vol. 23, pp. 7-53.

Kuczyńska-Koschany K.: “Trzy wiersze najważniejsze: Szymborska.” In: „Bce noэmbl жиды”. Antytotalitarne gesty poetyckie i kreacyjne wobec Zagłady oraz innych doświadczeń granicznych. Poznań 2013, pp. 275-283. 
LaChendro J.: Jeńcy sowieccy w KL Auschwitz. Oświęcim 2016.

Lietz Z.: Obozy jenieckie w Prusach Wschodnich 1939-1945. Warszawa 1982.

MACEK Z.: Hitlerowski obóz pracy przymusowej w Szebniach. Jasło 2013.

MACEK Z.: “Jeńcom głodem i zimnem uśpionym.” In: Hitlerowski obóz pracy przymusowej w Szebniach. Jasło 2013, p. 30.

Mackiewicz J.: Kontra. Paris 1957.

Majda J.: Świat poetycki Wisław Szymborskiej. Kraków 1996.

Matuszewski R.: Literatura polska 1939-1991. Warszawa 1992.

Matuszewski R.: Literatura współczesna dla kl. IV lub V szkoły średniej. 13th revised ed. Warszawa 1988.

Matuszewski R.: Polskaliteratura współczesna.Podręcznikpomocniczy dlaklasyIVliceum ogólnokształcacego oraz dla klasy V techników i liceów zawodowych. Warszawa 1976.

Matuszewski R.: Polska literatura wspótczesna. Podręcznik pomocniczy dla klasy IV liceum ogólnokształcacego oraz dla klasy $V$ techników i liceów zawodowych. 6th revised ed. Warszawa 1981.

Morawiec A.: Literatura w lagrze, lager w literaturze. Fakt - temat - metafora. Łódź 2009.

MorawiEc A.: "Literatura rosyjska wobec zagłady sowieckich jeńców wojennych.” Narracje o Zagładzie 2020, no. 6, pp. 80-114.

МотукA G.: “Tragedia jeńców sowieckich w czasie II wojny światowej w polskiej historiografii." In: J. Wојткошіак (ed.): Jeńcy sowieccy na ziemiach polskich $w$ czasie II wojny światowej. Warszawa 2015, pp. 17-33.

Nauschütz H.J.: “Na sympozjum w Oświęcimiu w październiku 1997 r.” Trans. J. Zacharska. In: J. PApuzińska, G. Leszczyński (eds.): Dzieciństwo i sacrum. Studia i szkice literackie. Warszawa 1998, pp. 57-62.

Newerly I.: Chłopiec z Salskich Stepów. Warszawa 1948.

Newerly I.: Chłopiec z Salskich Stepów. Warszawa 2010.

Newerly I.: "Prawdziwe przygody autora i bohaterów tej powieści." In: Chłopiec z Salskich Stepów. 19th ed. Warszawa 1974, pp. 187-201.

Omiljanowicz A.: "Koniec kommanda śmierci.” In: Sens życia. Warszawa 1971, pp. 68-80.

Pankowski M.: Z Auszwicu do Belsen. Przygody. Warszawa 2000.

Пиотровская А[стра]: Художественные искания современной польской титературь. Проза и поэзия 60-70-х годов. Москва 1979.

Pogozhev A.: Escape from Auschwitz. Trans. V. Krupnik, J. Armstrong. Barnsley 2007.

Pogożew A.: Ucieczka z Auschwitz. Trans. K. Bażyńska-Сhojnacka, P. Chojnacki. Warszawa 2011.

Погожев Андрей А., Стенькин Павел А.: Побег из Освеницма. Остаться в живых. Москва 2005.

Reid A.: “Szymborska Wisława.” In: T. Riggs (ed.): Reference Guide to Holocaust Literature. With introduction by J.E. Young. Detroit 2002, pp. 312-313.

Roszak J.: "Wezwałem cię po numerze. 172364, 119198, 132434 i inni." Przestrzenie Teorii 2012, no. 18, pp. 67-81.

Roszak J.: "Wstań, imię. Jeszcze Wisławy Szymborskiej." Polonistyka 2012, no. 11, pp. 43-45. 
Ryвак A.: “Losy jeńców sowieckich w Stalagu 319 w Chełmie.” In: J. Wojtkowiak (ed.): Jeńcy sowieccy na ziemiach polskich w czasie II wojny światowej. Warszawa 2015, pp. $35-61$.

Schirg O.: "Als das UKE [Universitätsklinikums Eppendorf] unter die Nazis fiel" [review: Hendrik van den Bussche: Die Hamburger Universitätsmedizin im Nationalsozialismus. Forschung - Lehre - Krankenversorgung. Berlin-Hamburg 2014]. Hamburger Abendblatt, https://www.abendblatt.de/hamburg/article133284418/Als-das -UKE-unter-die-Nazis-fiel.html [published 15.10.2014, accessed 28.04.2019].

Шлионская И.: Генерал Карбышев: он не стал Власовым, https://russian7.ru/post /karbyshev/ [published 14.10.2016, accessed 20.04.2019].

SNyder T.: Bloodlands. Europe between Hitler and Stalin. New York 2010.

Szmaglewska S.: Dymy nad Birkenau. Warszawa 1945.

Szmaglewska S.: Smoke over Birkenau. Trans. J. Rynas. Auckland 2015.

Szmaglewska S.: “Zagrycha." In: Chleb i nadzieja. Opowiadania. 2nd extended ed. Warszawa 1960, pp. 56-67.

Szymborska W.: “A Great Number.” Trans. C. MiŁosz, http://www.ronnowpoetry.com /contents/szymborska/GreatNumber.html [accessed 2.03.2020].

Szymborska W.: “Dlatego żyjemy.” In: Dlatego żyjemy. Warszawa 1952, pp. 5-7.

Szymborska W.: “Jeszcze.” In: Wołanie do Yeti. Kraków 1957, pp. 37-38.

Szymborska W.: “Obóz głodowy pod Jasłem.” Nowa Kultura 1962, no. 5, p. 1.

Szymborska W.: “Obóz głodowy pod Jasłem.” Nowiny [Rzeszów] 1988, insert Widnokrąg, no. 17, p. 1.

Szymborska W.: “Obóz głodowy pod Jasłem.” In: Sól. Warszawa 1962, pp. 25-26.

Szymborska W.: “Obóz głodowy pod Jasłem.” In: R. Matuszewski (ed.): Wiersze polskich poetów współczesnych. Wybór. Książka pomocnicza dla uczniów klas IV i V szkół średnich. Warszawa 1976, pp. 172-173.

Szymborska W.: “Obóz głodowy pod Jasłem.” In: R. Krynicki (ed.): Wiersze wybrane. Selection and arrangement by the author. A new, extended ed. Kraków 2012, pp. 80-81.

Szymborska W.: “Obóz głodowy pod Jasłem.” In: Wybór poezji. Ed. W. Ligęza and with his introduction. Wrocław 2016, pp. 94-95.

Szymborska W.: “Szukam słowa.” Dziennik Polski 1945, no. 39, supplement Walka, no. 3 , p. 3 .

Szymborska W.: “The Hunger Camp at Jasło.” Trans. G. Drabik, A. Flint, https:// www.poemhunter.com/poem/hunger-camp-at-jaslo/ [accessed 10.01.2020].

Szymborska W.: “Transport Żydów 1943.” Dziennik Literacki 1948, no. 17, p. 2.

Szymborska W.: “Wielka liczba.” In: Wielka liczba. Warszawa 1976, pp. 5-6.

Świerz M.: "Podmiot liryczny w wierszu Szymborskiej Obóz głodowy pod Jasłem." Polonistyka 1983, no. 4, pp. 257-259.

Wasilewski W.: "Pamięć Katynia. Działania opozycji." Biuletyn Instytutu Pamięci Narodowej 2009, no. 5/6, pp. 60-69.

Wiatr A.: Syzyf w piekle współczesności. Rzecz o Wisławie Szymborskiej. Warszawa 1996.

Wieliczко M.: Jasielskie w latach drugiej wojny światowej. Warszawa 1974.

Wieliczko M.J.: “Obóz wyniszczenia w Szebniach w latach 1941-1944.” Rocznik Przemyski 1970, vol. 13/14, pp. 237-264. 
Zabierowski S.: Szebnie. Dzieje obozów hitlerowskich. Rzeszów 1985.

[Zarembina N.]: The Camp of Death. With a foreword by J.L. Adamson. [Trans. B. Gadomska]. London 1944.

[Zarembina N.]: Obóz śmierci. [Warszawa] 1942.

Arkadiusz Morawiec

Literatura polska wobec zagłady sowieckich więźniów wojennych

Abstrakt: Przedmiotem artykułu jest motyw i temat sowieckich jeńców wojennych w literaturze polskiej. Zaprezentowano w nim fakty historyczne, będące źródłem ujęć literackich, dotyczące skomplikowanego losu sowieckich jeńców podczas wojny niemiecko-sowieckiej (1941-1945) i po jej zakończeniu. Ukazano także polityczne i ideologiczne determinanty literackiego wizerunku jeńca. Przedmiotem analiz są zarówno utwory fikcjonalne, jak i wspomnieniowe, między innymi Chłopiec z Salskich Stepów Igora Newerlego, Zagrycha Seweryny Szmaglewskiej, Anus mundi Wiesława Kielara. Szczególną uwagę poświęcono wierszowi Obóz głodowy pod Jasłem Wisławy Szymborskiej.

SŁOWA KLUCZE: literatura polska, temat, motyw, ludobójstwo, zbrodnie nazistowskie, zbrodnie wojenne, sowieccy jeńcy wojenni

Arkadiusz Morawiec - prof. dr hab., literaturoznawca i krytyk literacki, pracuje w Zakładzie Literatury Polskiej XX i XXI wieku Uniwersytetu Łódzkiego. Zajmuje się historią literatury polskiej XX i XXI wieku, w szczególności pisarstwem obrazującym totalitaryzm i ludobójstwo (w tym literaturą obozową i literaturą Holokaustu) oraz pisarstwem jako formą pamięci. Autor książek: Poetyka opowiadań Gustawa Herlinga-Grudzińskiego. Autentyzm - dyskursywność - paraboliczność (2000), Seweryna Szmaglewska (1916-1992). Bibliografia (2007), Literatura w lagrze, lager w literaturze. Fakt temat - metafora (2009), Polityczne, prywatne, metafizyczne. Szkice o literaturze polskiej ostatnich dziesięcioleci (2014), Zofia Romanowiczowa. Pisarka nie tylko emigracyjna (2016), Literatura polska wobec ludobójstwa. Rekonesans (2018).

Arkadiusz MorawiEc, associate professor in the field of literary studies and a literary critic, works at the Department of the 20th- and 21st-Century Polish Literature of the University of Łódź. In his research he focuses on the Polish literature of the 20th and 21 st centuries, in particular on writing depicting totalitarianism and genocide (including Lager/Gulag literature and Holocaust literature), as well as writing as a form of memory. He is the author of: Poetyka opowiadań Gustawa Herlinga-Grudzińskiego. Autentyzm dyskursywność - paraboliczność (2000), Seweryna Szmaglewska (1916-1992). Bibliografia (2007), Literatura $w$ lagrze, lager $w$ literaturze. Fakt - temat - metafora (2009), Polityczne, prywatne, metafizyczne. Szkice o literaturze polskiej ostatnich dziesięcioleci (2014), Zofia Romanowiczowa. Pisarka nie tylko emigracyjna (2016), Literatura polska wobec ludobójstwa. Rekonesans (2018). 